\title{
Arsenic exposure and risk of preeclampsia in a Mexican mestizo population
}

\author{
Ada Sandoval-Carrillo', Edna M. Méndez-Hernández², Elizabeth I. Antuna-Salcido', Sergio M. Salas-Pacheco', \\ Fernando Vázquez-Alaniz ${ }^{3}$, Alfredo Téllez-Valencia², Marisela Aguilar-Durán', Marcelo Barraza-Salas ${ }^{4}$, \\ Francisco X. Castellanos-Juárez', Osmel La Llave-León ${ }^{1}$ and José M. Salas-Pacheco ${ }^{1 *}$
}

\begin{abstract}
Background: Exposure to arsenic in drinking water has been associated with various complications of pregnancy including fetal loss, low birth weight, anemia, gestational diabetes and spontaneous abortion. However, to date, there are no studies evaluating its possible association with preeclampsia.

Methods: This case-control study involved 104 preeclamptic and 202 healthy pregnant women. The concentrations of arsenic in drinking water and urine were measured using a Microwave Plasma-Atomic Emission Spectrometer.

Results: We found relatively low levels of arsenic in household tap water (range of 2.48-76.02 $\mu \mathrm{g} / \mathrm{L}$ ) and in the urine of the participants $(7.1 \mu \mathrm{g} / \mathrm{L}$ vs $6.78 \mu \mathrm{g} / \mathrm{L}$ in cases and controls, respectively).

Conclusions: The analysis between groups showed for the first time that at these lower levels of exposure there is no association with preeclampsia.
\end{abstract}

Keywords: Preeclampsia, Arsenic, Drinking water

\section{Background}

Preeclampsia (PE) is a disorder peculiar to pregnancy and a major cause of maternal death and adverse fetal outcome [1]. In developing countries where access to health care is limited, PE is a leading cause of maternal mortality, with estimates of more than 60,000 maternal deaths per year [2] Although the exact pathophysiologic mechanisms of PE remain elusive, studies to date have implicated multiple processes, including the following: abnormal trophoblastic invasion, vasospasm, platelet activation, imbalance in the vasomotor-regulating factors and placental ischemia [3]. PE is characterized by increased oxidative stress due to the imbalance between lipid peroxidation and antioxidant defense mechanisms, leading to endothelial dysfunction and free radical mediated cell injury [4].

Arsenic-contaminated drinking water represents a major public health problem internationally [5-8].

\footnotetext{
* Correspondence: jsalas_pacheco@hotmail.com

${ }^{1}$ Institute of Scientific Research, Juarez University of the State of Durango, Av. Universidad y Fanny Anitua s/n. Col. Centro, C.P. 34000 Durango, Dgo, Mexico

Full list of author information is available at the end of the article
}

The World Health Organization (WHO) and U.S. Environmental Protection Agency (EPA) standard for arsenic level in drinking water is $10 \mu \mathrm{g} / \mathrm{L}[9,10]$. Arsenic (As) is an established carcinogen and is also associated with a wide range of other chronic illnesses, such as diabetes, hypertension, and vascular diseases [11].

Oxidative stress has been identified as an important mechanism of As toxicity and carcinogenicity. In particular, As induces oxidative DNA damage and lipid peroxidation [12-16]. Oxidative stress and disrupted antioxidant systems have been shown to be involved in a wide range of pregnancy complications such as impaired fetal growth, PE, and miscarriage $[17,18]$.

Besides the generation of oxidative stress as a possible mechanism by which As may be associated with PE, Shin Le et al. reported that exposure to environmentally relevant concentrations of As $(2.5 \mu \mathrm{M}$ of $\mathrm{AsNaO} 2)$ inhibit the migration of EVT cells (a human extravillous trophoblast cell line) in vitro, therefore, a similar mechanism may be occurring in vivo [19].

Several studies have been conducted to determine the association between chronic As exposure and adverse pregnancy outcome. Excess spontaneous abortion, 
stillbirth, and preterm birth rates among women with chronic As exposure have been reported [20-23]. However, to date there are no reports that show an association between As exposure and PE. This study evaluates whether As exposure from drinking water is associated with PE in a population of northern Mexico.

\section{Methods}

\section{Patient recruitment}

This prospective case-control study was approved by the Research Ethics Committee of the General Hospital of the Ministry of Health of Durango, Mexico in accordance with the Code of Ethics of the Declaration of Helsinki. Signed informed consent was obtained from all patients and controls before participation in the study. The sample size was calculated using the formula $n=\left(\mathrm{Z}_{\alpha / 2}+\mathrm{Z}_{\beta}\right)^{2} \dot{\mathrm{p}}(1-\dot{\mathrm{p}})(\mathrm{r}+1) / \mathrm{d}^{2} \mathrm{r}$. The $\mathrm{n}$ needed to achieve $80 \%$ power with an alpha of 0.05 was 94 (cases) and 188 (controls). Finally, we recruited 104 women diagnosed with PE (cases) and 202 healthy pregnant women (controls). The inclusion criteria were all those women diagnosed with mild $\mathrm{PE}$ (blood pressure $(\mathrm{BP}) \geq 140 / 90 \mathrm{mmHg}$ and proteinuria $\geq 30 \mathrm{mg} / \mathrm{dL}$ ), severe $\mathrm{PE}(\mathrm{BP} \geq 160 / 110 \mathrm{mmHg}$ and proteinuria $\geq 2000 \mathrm{mg} / \mathrm{dL})$ and eclampsia (defined as occurrence, in a woman with $\mathrm{PE}$, of seizures that cannot be attributed to other causes). The control group was conformed by healthy pregnant women attending the same hospital; without hypertensive, pathological or metabolic disorders during pregnancy. Follow up was given to the control group to corroborate the normality of the blood pressure values.

\section{Sample collection}

Within 1-3 weeks of delivery, a drinking water sample was collected at the homes of each of the study participants. Drinking-water samples were collected based on the subject's primary drinking water source. Maternal spot urine samples were collected at the hospital before delivery and immediately transported to the laboratory. Samples were stored at $-80{ }^{\circ} \mathrm{C}$ until processing.

\section{Detection of As in drinking water and urine}

The concentrations of As in drinking water (DW) and urine were measured in the toxicology laboratory of Scientific Research Institute of the Universidad Juárez del Estado de Durango (UJED) using a Microwave Plasma-Atomic Emission Spectrometer (MP-AES 4100). The Trace Elements in Water standard reference material (SRM 1643e) (National Institute of Standards and Technology, Gaithersburg, MD) was used for quality control. The limit of detection for As in DW by MP-AES was $0.5 \mu \mathrm{g}$ As/L. For urine analysis, six point calibration curves were prepared. To compensate for variation in the dilution of the urine (caused by variation in fluid intake, time of sampling, temperature, and physical activity), we adjusted the concentrations by specific gravity.

\section{Statistical analysis}

Independent sample Student's $t$-tests were performed using SPSS software (version 15.0; SPSS Inc., Chicago, IL, USA). Odds ratios (ORs) as estimates of relative risk of the disease were calculated with $95 \%$ confidence intervals (95\% CIs). The ORs were adjusted for variations in age and weeks of pregnancy by means of a multivariate logistic regression model. Mann-Whitney $U$ test was used when the data were not normally distributed. For analysis, our patients were stratified into 3 groups based on As levels in DW (Table 3). The Group 1 (G1) presented levels lower than $10 \mu \mathrm{g} / \mathrm{L}$, group 2 (G2) levels between $10.1 \mu \mathrm{g} / \mathrm{L}$ and $25 \mu \mathrm{g} / \mathrm{L}$ and group 3 (G3) levels above $25.1 \mu \mathrm{g} / \mathrm{L}$

\section{Results}

Clinical characteristics for controls and cases are shown in Table 1. Of the 104 women diagnosed with PE, 13 had mild PE, 72 severe PE and 19 eclampsia. Variables that showed a difference between groups were family history of PE, systolic and diastolic blood pressure $(\mathrm{mm} \mathrm{Hg})$, weeks of pregnancy and body mass index (Table 1). The range of As concentration in household tap water was $2.48-76.02 \mu \mathrm{g} / \mathrm{L}$ with more than $95 \%$ of the participants having As levels higher than $10 \mu \mathrm{g} / \mathrm{L}$. The mean concentration of As in DW was $39.58 \mu \mathrm{g} / \mathrm{L}$ and $40.49 \mu \mathrm{g} / \mathrm{L}$ for cases and controls, respectively; there were no statistically significant differences (Table 2, $p=0.816$ ). While the WHO sets a maximum concentration of $10 \mu \mathrm{g} / \mathrm{L}$ in DW, the authorities in Mexico have set a maximum concentration of $25 \mu \mathrm{g} / \mathrm{L}$ (NOM-127-SSA1-1994) [24]. For this reason, the OR was estimated stratifying our patients into 3 groups based on As levels in DW. The results of Table 3 show that although the group exposed to concentrations above $25 \mu \mathrm{g} / \mathrm{L}$ presents an increased risk $(\mathrm{OR}=1,715)$. This difference is not statistically significant $(p=0.214)$.

Table 1 Clinical characteristics for cases and controls

\begin{tabular}{llll}
\hline Clinical features & Controls $(n=202)$ & Cases $(n=104)$ & P-value \\
\hline Age (years) & $24.30(7.078)^{\mathrm{a}}$ & $24.39(7.349)^{\mathrm{a}}$ & $.92^{\mathrm{b}}$ \\
Weeks of pregnancy & $37.49(3.96)^{\mathrm{a}}$ & $35.82(3.97)^{\mathrm{a}}$ & $0.001^{\mathrm{b}}$ \\
Systolic BP (mm Hg) & $111.74(10.82)^{\mathrm{a}}$ & $158.36(16.41)^{\mathrm{a}}$ & $<0.0001^{\mathrm{b}}$ \\
Diastolic BP (mm Hg) & $70.39(9.97)^{\mathrm{a}}$ & $101.21(10.3)^{\mathrm{a}}$ & $<0.0001^{\mathrm{b}}$ \\
Number of pregnancies & $2.26(1.40)^{\mathrm{a}}$ & $2.34(2.49)^{\mathrm{a}}$ & $0.718^{\mathrm{b}}$ \\
Body mass index & $24.61(5.22)^{\mathrm{a}}$ & $27.63(5.82)^{\mathrm{a}}$ & $<0.0001^{\mathrm{b}}$ \\
PE antecedent & $13 / 202$ & $14 / 104$ & $0.045^{\mathrm{c}}$ \\
\hline
\end{tabular}

${ }^{\mathrm{a}}$ Mean \pm Standard deviation

bIndependent sample $T$ test

${ }^{\mathrm{c}}$ Chi square test 
Table 2 Water and urine arsenic levels in cases and controls

\begin{tabular}{|c|c|c|c|c|}
\hline Arsenic $\mu \mathrm{g} / \mathrm{L}$ & $\begin{array}{l}\text { Controls } \\
(n=202)\end{array}$ & $\begin{array}{l}\text { Cases } \\
(n=104)\end{array}$ & & P-value \\
\hline Water & $40.49(16.40)^{a}$ & $39.58(26.43)^{a}$ & & $0.816^{b}$ \\
\hline \multirow[t]{2}{*}{ Urine } & $6.78(3.48)^{a}$ & $7.1(5.74)^{\mathrm{a}}$ & & $0.428^{c}$ \\
\hline & & $\begin{array}{l}\text { Mild PE } \\
n=13\end{array}$ & $\begin{array}{l}\text { Severe PE/eclampsia } \\
n=91\end{array}$ & P-value \\
\hline Water & & $46.03(20.65)^{a}$ & $38.62(26.87)^{a}$ & $0.519^{b}$ \\
\hline Urine & & $7.82(6.87)^{\mathrm{a}}$ & $7.03(5.67)^{a}$ & $0.788^{c}$ \\
\hline
\end{tabular}

${ }^{a}$ Mean \pm Standard deviation

${ }^{\mathrm{b}}$ Independent sample $T$ test

' Mann-Whitney $U$ test

Total urinary As concentration (U-tAs) was also evaluated. The mean concentration of U-tAs was $7.1 \mu \mathrm{g} / \mathrm{L}$ and $6.78 \mu \mathrm{g} / \mathrm{L}$ for cases and controls, respectively; there were no statistically significant differences (Table 2, $p=0.428)$. With the intention to establish whether As may be associated with the severity of PE, the cases were stratified in mild PE and severe PE/eclampsia. The results of Table 2 show that there is no statistically significant differences in the U-tAs $(p=0.788)$. The risk of PE by U-tAs was estimated piling up to the patients in tertiles. The results in Table 3 show that at these levels, U-tAs is not a risk for PE.

Finally, we evaluated the correlation between As in DW and U-tAs. We observed an increase in the U-tAs associated with higher levels of As in DW. G1 presented a mean of $3.39 \mu \mathrm{g} / \mathrm{L}, \mathrm{G} 2$ of $6.67 \mu \mathrm{g} / \mathrm{L}$ and G3 of $7.8 \mu \mathrm{g} / \mathrm{L}$. However, the correlation coefficient was very low $\left(R^{2}=0.036\right)$.

\section{Discussion}

To our knowledge this is the first study that evaluates if As exposure from DW is associated with PE. The As concentrations in household tap water $(2.48-76.02 \mu \mathrm{g} / \mathrm{L})$ were consistent with those previously found by our working group in the wells that provide DW to the city of Durango [25, 26]. Although these concentrations are not as high as those reported in other countries [27-30] or even in other regions of our own locality [31], there is a tremendous interest in the evaluation of regions with low or moderate As exposure in accordance with the increasingly clear evidence that relatively low levels of As can have health effects. Our comparative analysis between controls and cases evidenced no statistically significant differences. In addition, no differences were found in the analysis based on the severity of the PE.

The analysis of U-tAs showed a mean of $7.1 \mu \mathrm{g} / \mathrm{L}$ for cases and $6.78 \mu \mathrm{g} / \mathrm{L}$ for controls. These U-tAs levels are clearly lower than those reported among pregnant women in Bangladesh $(80 \mu \mathrm{g} / \mathrm{L})$ [32] and even lower than those reported in pregnant women in the nearby region known as Comarca Lagunera $(23.3 \mu \mathrm{g} / \mathrm{L})$ [33]. In our study we didn't find an association between U-tAs and PE or an association with the severity of PE. Recently, Joy-Mendez et al. found no association between serum As levels and blood pressure in a cohort of pregnant women from Mexico city [34]. They reported a mean of $15.2 \mu \mathrm{g} / \mathrm{L}$ of As in serum. Although they don't evaluate PE, our results can be considered similar.

In contrast to our results, several reports have associated As exposure with pregnancy complications including low weight of the newborn [35], fetal death [36], gestational diabetes [32], anemia [37] and spontaneous abortions [38], however, these associations appear at significantly higher levels of As (e. g., fetal death, U-tAs $>200 \mu \mathrm{g} / \mathrm{L}$ or spontaneous abortions, As in $\mathrm{DW}>100 \mu \mathrm{g} / \mathrm{L})$.

Our results could be interpreted on the one hand, as a confirmation of no association between As and PE, at least at these low levels. On the other hand, they might suggest that we need higher levels of As exposure to be able to observe the association.

Our study has some limitations. Although the participants state that their main source of water is from the tap, we can't rule out that As can come from other sources of drinking water (e.g., bottled water), some

Table 3 Odds ratio estimation by ranges of arsenic in water and urine

\begin{tabular}{|c|c|c|c|c|c|}
\hline Water arsenic & $\mathrm{OR}^{*}(95 \% \mathrm{Cl})$ & P-value & Urine arsenic & $\mathrm{OR}^{*}(95 \% \mathrm{Cl})$ & P-value \\
\hline $\begin{array}{l}\text { Group } 1^{\text {a }} \\
n=10\end{array}$ & Reference & & 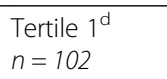 & Reference & \\
\hline $\begin{array}{l}\text { Group } 2^{b} \\
n=69\end{array}$ & $1.486(0.200-11.025)$ & 0.698 & $\begin{array}{l}\text { Tertile } 2^{e} \\
n=102\end{array}$ & $1.400(0.748-2.621)$ & 0.698 \\
\hline $\begin{array}{l}\text { Group } 3^{c} \\
n=227\end{array}$ & $1.715(0.732-4.019)$ & 0.214 & $\begin{array}{l}\text { Tertile } 3^{f} \\
n=102\end{array}$ & $0.788(0.411-1.512)$ & 0.214 \\
\hline
\end{tabular}

${ }^{\mathrm{a}}$ DW As $<10 \mu \mathrm{g} / \mathrm{L}$

${ }^{b}$ DW As $10.1-25 \mu \mathrm{g} / \mathrm{L}$

c DW As $>25 \mu \mathrm{g} / \mathrm{L}$

${ }^{d} \mathrm{U}$-tAs $\leq 7.4956 \mu \mathrm{g} / \mathrm{L}$

e U-tAs $>7.4956 \leq 11.4911 \mu \mathrm{g} / \mathrm{L}$

f $U$-tAs $>11.4911 \mu \mathrm{g} / \mathrm{L}$

* ORs were adjusted for age and weeks of pregnancy 
food, or by some occupational exposure. Another limitation is that we didn't find high levels of U-tAs, so we can't establish in our study if higher levels of urinary As are or are not associated with PE.

The evaluation of pregnant women with higher levels of As as well as the analysis of other factors (e.g., genetic or nutritional) becomes necessary to confirm and strengthen our findings.

\section{Conclusions}

First, it is shown that the majority of our population is exposed to As levels higher than that established by the WHO. In addition, our work suggests for the first time that there is no association between As exposure and PE.

\section{Abbreviations}

As, arsenic; DW, drinking water; EPA, environmental protection agency; ORs, odds ratios; PE, preeclampsia; UJED, Universidad Juárez del Estado de Durango; U-tAs, urinary arsenic concentration; WHO, World Health Organization

\section{Acknowledgements}

We thank all General Hospital of the Ministry of Health of Durango staff for their participation in data collection.

\section{Funding}

This work was supported by Grant 2011-01-161553 from CONACYT/México to J.M. Salas-Pacheco. A. Sandoval-Carrillo was supported by a doctoral fellowship from CONACYT.

\section{Availability of data and materials}

The data will not be shared in order to protect the participants' anonymity.

\section{Authors' contributions}

EMMH, ATV and OLL carried out the statistical analysis and helped to draft the manuscript. EIAS, SMSP, FVA and MBS carried out the integration of groups and sampling of household tap water. FXCJ and MAD carried out the arsenic determinations. JMSP and ASC conceived of the study, and participated in its design and coordination and drafted the manuscript. All authors have read and approved the final manuscript.

\section{Competing interests}

The authors declare that they have no competing interests.

\section{Consent for publication}

Not applicable.

\section{Ethics approval and consent to participate}

This study was approved by the Research Ethics Committee of the General Hospital of the Ministry of Health of Durango, Mexico. Informed signed consent was obtained from study participants.

\section{Author details}

${ }^{1}$ Institute of Scientific Research, Juarez University of the State of Durango, Av. Universidad y Fanny Anitua s/n. Col. Centro, C.P. 34000 Durango, Dgo, Mexico. ${ }^{2}$ Faculty of Medicine and Nutrition, Juarez University of the State of Durango, Zip Code 34000 Durango, Mexico. ${ }^{3}$ General Hospital 450, Health Services, Durango Zip Code 34000, Mexico. ${ }^{4}$ Faculty of Chemical Sciences, Juarez University of the State of Durango, Zip Code 34000 Durango, Mexico.

Received: 27 October 2015 Accepted: 28 June 2016

Published online: 11 July 2016

\section{References}

1. World Health Organization. Recommendations for prevention and treatment of pre-eclampsia and eclampsia. Geneva: World Health Organization; 2011.
2. World Health Organization. Make Every Mother and Child Count: The World Health Report. Geneva: World Health Organization; 2005.

3. Roberts JM, Redman C. Pre-eclampsia: more than pregnancy-induced hypertension. Lancet. 1993;341(8858):1447-51.

4. Siddiqui IA, Jaleel A, Tamimi W, Al Kadri HM. Role of oxidative stress in the pathogenesis of preeclampsia. Arch Gynecol Obstet. 2010;282(5):469-74.

5. Craw D, Koons P, Chappell D. Arsenic distribution during formation and capping of an oxidised sulphidic minesoil, Macraes mine, New Zealand. J Geochem Explor. 2002;76(1):13-29.

6. Chen C-J, Hsueh Y-M, Lai M-S, Shyu M-P, Chen S-Y, Wu M-M, et al. Increased prevalence of hypertension and long-term arsenic exposure. Hypertension. 1995;25(1):53-60.

7. Chilvers D, Peterson P. Global cycling of arsenic. In: Hutchinson TC, Meema KM, editors. Lead, mercury, cadmium and arsenic in the environment. John Wiley \& Sons Ltd; 1987. p. 279-301.

8. Mukherjee A, Sengupta MK, Hossain MA, Ahamed S, Das B, Nayak B, et al. Arsenic contamination in groundwater: a global perspective with emphasis on the Asian scenario. J Health Popul Nutr. 2006;24(2):142-63.

9. World Health Organization. Guidelines for drinking-water quality. Fourth Edition. Geneva: World Health Organization; 2011.

10. Agency for Toxic Substances and Disease Registry. Toxicological Profile for Arsenic (Update). Atlanta: US Public Health Service, US DHHS; 2005.

11. Humans IWGotEoCRt, Organization WH, Cancer IAfRo. Some Drinking-Water Disinfectants and Contaminants, Including Arsenic. Lyon: IARC; 2004.

12. Fujino Y, Guo X, Liu J, Matthews IP, Shirane K, Wu K, et al. Chronic arsenic exposure and urinary 8-hydroxy-2'-deoxyguanosine in an arsenicaffected area in Inner Mongolia, China. J Expo Sci Environ Epidemiol. 2005;15(2):147-52.

13. Pineda-Zavaleta AP, García-Vargas G, Borja-Aburto VH, Acosta-Saavedra LC Aguilar EV, Gómez-Muñoz AS, et al. Nitric oxide and superoxide anion production in monocytes from children exposed to arsenic and lead in region Lagunera, Mexico. Toxicol Appl Pharmacol. 2004;198(3):283-90.

14. Wang T-C, Jan K-Y, Wang AS, Gurr J-R. Trivalent arsenicals induce lipid peroxidation, protein carbonylation, and oxidative DNA damage in human urothelial cells. Mutat Res Fundam Mol Mech Mutagenesis. 2007;615(1):75-86.

15. Maharjan M, Watanabe C, Ahmad SA, Umezaki M, Ohtsuka R. Mutual interaction between nutritional status and chronic arsenic toxicity due to groundwater contamination in an area of Terai, lowland Nepal. J Epidemiol Community Health. 2007;61(5):389-94.

16. Mo J, Xia Y, Wade TJ, Schmitt M, Le XC, Dang R, et al. Chronic arsenic exposure and oxidative stress: OGG1 expression and arsenic exposure, nail selenium, and skin hyperkeratosis in Inner Mongolia. Environ Health Perspect. 2006;1 14:835-41.

17. Sugino N, Takiguchi S, Umekawa T, Heazell A, Caniggia I. Oxidative stress and pregnancy outcome: a workshop report. Placenta. 2007;28:S48-50.

18. Jauniaux E, Poston L, Burton GJ. Placental-related diseases of pregnancy: involvement of oxidative stress and implications in human evolution. Hum Reprod Update. 2006;12(6):747-55.

19. Li C-S, Loch-Caruso R. Sodium arsenite inhibits migration of extravillous trophoblast cells in vitro. Reprod Toxicol. 2007;24(3):296-302.

20. Ahmad SA, Sayed M, Barua S, Khan MH, Faruquee M, Jalil A, et al. Arsenic in drinking water and pregnancy outcomes. Environ Health Perspect. 2001;109(6):629.

21. Rahman A, Persson L- $\AA$, Nermell B, El Arifeen S, Ekström E-C, Smith AH, et al. Arsenic exposure and risk of spontaneous abortion, stillbirth, and infant mortality. Epidemiology. 2010;21(6):797-804.

22. Rahman $A$, Vahter $M$, Smith AH, Nermell B, Yunus M, El Arifeen $S$, et al. Arsenic exposure during pregnancy and size at birth: a prospective cohort study in Bangladesh. Am J Epidemiol. 2009;169(3):304-12.

23. Naujokas MF, Anderson B, Ahsan H, Aposhian HV, Graziano J, Thompson C, et al. The broad scope of health effects from chronic arsenic exposure: update on a worldwide public health problem. Environ Health Perspect. 2013;121(3):295-302.

24. Diario Oficial de la Federación. Modificación a la norma oficial Mexicana NOM-127-SSA1-1994. Salud ambiental, agua para uso y consumo humano. Límites permisibles de calidad y tratamientos a que debe someterse el agua para su potabilización. México City: Diario Oficial de la Federación; 2000 .

25. Antuna-Salcido El. Genotipificación de los polimorfismos nulos de los genes GSTT1 y GSTM1 en población expuesta a arsénico del estado de Durango. Durango: Universidad Juárez del Estado de Durango; 2013. 
26. Salas-Pacheco SM. Genotipificación de los polimorfismos Met287Thr del gen AS3MT y Ala222Val del gen MTHFR en población infantil expuesta a arsénico de la ciudad de Durango. Durango: Universidad Juárez del Estado de Durango; 2012

27. Shankar S, Shanker U. Arsenic contamination of groundwater: a review of sources, prevalence, health risks, and strategies for mitigation. Sci World J. 2014;2014.

28. Harper KN, Liu X, Hall MN, llievski V, Oka J, Calancie L, et al. A dose-response study of arsenic exposure and markers of oxidative damage in Bangladesh. J Occup Environ Med. 2014;56(6):652-8.

29. Mitchell VL. Health risks associated with chronic exposures to arsenic in the environment. Rev Mineral Geochem. 2014;79(1):435-49.

30. Bhatia S, Balamurugan G, Baranwal A. High arsenic contamination in drinking water hand-pumps in Khap Tola, West Champaran, Bihar, India. Front Environ Sci. 2014:2:49.

31. Del Razo LM, García-Vargas GG, Valenzuela OL, Castellanos EH, Sánchez-Peña LC, Currier JM, et al. Exposure to arsenic in drinking water is associated with increased prevalence of diabetes: a crosssectional study in the Zimapan and Lagunera regions in Mexico. Environ Health. 2011;10(1):73-84.

32. Vahter ME, Li L, Nermell B, Rahman A, Arifeen SE, Rahman M, et al. Arsenic exposure in pregnancy: a population-based study in Matlab, Bangladesh. J Health Popul Nutr. 2006;24:236-45.

33. Laine JE, Bailey KA, Rubio-Andrade M, Olshan AF, Smeester L, Drobná Z, et al. Maternal arsenic exposure, arsenic methylation efficiency, and birth outcomes in the biomarkers of exposure to ARsenic (BEAR) pregnancy cohort in Mexico. Environ Health Perspect. 2015;123(2):186.

34. Alegría-Méndez M L-FH, García Vargas G, Fragoso J M, Hernández-Mora F J, Téllez-Rojo M M, Wright R O. Concentración sérica de arsénico total, y su relación con la presión arterial de mujeres embarazadas en una cohorte en la Ciudad de México. México. 2013.

35. Huyck KL, Kile ML, Mahiuddin G, Quamruzzaman Q, Rahman M, Breton CV, et al. Maternal arsenic exposure associated with low birth weight in Bangladesh. J Occup Environ Med. 2007;49(10):1097-104.

36. Rahman A, Vahter M, Ekström E-C, Rahman M, Mustafa AHMG, Wahed MA et al. Association of arsenic exposure during pregnancy with fetal loss and infant death: a cohort study in Bangladesh. Am J Epidemiol. 2007;165(12):1389-96.

37. Hopenhayn C, Bush HM, Bingcang A, Hertz-Picciotto I. Association between arsenic exposure from drinking water and anemia during pregnancy. J Occup Environ Med. 2006;48(6):635-43.

38. Sen J, Chaudhuri A. Arsenic exposure through drinking water and its effect on pregnancy outcome in Bengali women. Arch Ind Hyg Toxicol. 2008:59(4):271-5.

\section{Submit your next manuscript to BioMed Central and we will help you at every step:}

- We accept pre-submission inquiries

- Our selector tool helps you to find the most relevant journal

- We provide round the clock customer support

- Convenient online submission

- Thorough peer review

- Inclusion in PubMed and all major indexing services

- Maximum visibility for your research

Submit your manuscript at www.biomedcentral.com/submit

C Biomed Central 